\title{
A EMANCIPAÇÃo OCIOSA, OU, O QUE NOS PROPÕE A TEORIA CRÍTICA DE MARX?
}

\author{
Amaro Fleck ${ }^{1}$
}

\begin{abstract}
RESUMO: No presente artigo, traço, rapidamente, a perspectiva a partir da qual Marx constrói sua crítica ao capitalismo, a saber, a diferença entre o potencial transformador da técnica tal como desenvolvida sob o modo capitalista de produção e a sua realidade efetiva nesse mesmo sistema (parte 1). Com isso feito, argumento que a crítica de Marx ao sistema capitalista consiste em grande parte no fato de a valorização permanente do capital ser a meta da produção, uma finalidade irracional e que cria uma dominação abstrata desse mecanismo sobre os indivíduos (parte 2), de modo a, por fim, repensar o sentido de emancipação no pensamento marxiano tardio, sustentando, sobretudo, que se trata de uma emancipação dessa dominação abstrata que culmina, também, em uma emancipação do trabalho em prol da criação de cada vez mais tempo disponível (parte 3).
\end{abstract}

PALAVRAS-CHAVE: Karl Marx. Crítica ao capitalismo. Crítica do trabalho. Emancipação. Tempo disponível.

O pensamento crítico radical tem assumido, nos últimos anos, uma postura meramente reativa. Com a ofensiva neoliberal das últimas décadas e o desabamento do bloco soviético, e, portanto, com o findar do "socialismo realmente existente", houve uma "debandada" das críticas ao próprio processo capitalista como tal, em prol de críticas a aspectos singulares ou configurações momentâneas deste. Desse modo, muito se tem escrito sobre a globalização e muito se tem criticado o neoliberalismo, mas pouco se tem tentado compreender e criticar a continuidade da dominação capitalista, no neoliberalismo globalizado. Torna-se difícil, assim, diferenciar as críticas radicais ao capitalismo, de cunho marxiano, daquelas críticas dirigidas a certos aspectos do capitalismo, algo que poderia ser denominado, quiçá, de keynesianismo de esquerda. Há muito se sente a falta de uma alternativa desejável, na qual a crítica encontraria ancoradouro.

\footnotetext{
${ }^{1}$ Doutorando em Filosofia na UFSC e bolsista CAPES. Endereço eletrônico: amarofleck@hotmail. com. Agradeço as leituras e sugestões de Alessandro Pinzani, Marcelo Alves e Joel Klein.
} 
Meu propósito aqui é, de certa forma, contribuir no resgate de uma dimensão emancipadora do pensamento crítico radical. Através de uma releitura das obras tardias marxianas, isto é, de O Capital e de seus esboços preparatórios, almejo enfatizar a dimensão emancipadora de tal teoria crítica como uma proposta ainda viável, ou melhor, hoje ainda mais atual do que na época na qual foi escrita, capaz de entender e questionar as agruras do mundo capitalista contemporâneo. Tal releitura tenta oferecer, com isso, uma teoria que é crítica tanto das reminiscências do socialismo realmente existente e do marxismo, em suas versões mais tradicionais, quanto das alternativas "realistas" que abandonam a pretensão de criticar o capitalismo em suas estruturas mais profundas.

A releitura da qual trato foi inicialmente proposta por Moishe Postone e é compartilhada, ao menos em suas linhas gerais, por Anselm Jappe e Antoine Artous, dentre outros. Tal releitura do Marx tardio rompe com as interpretações tradicionais que têm sido feitas sobre esse autor por vários motivos: não considera a classe proletária a redentora da humanidade, tampouco o porta-voz da revolução (mas sim uma parte, dentre outras, das espoliadas pela dominação abstrata capitalista); não acredita que o trabalho seja a essência do homem, nem que o homem se distingue dos demais animais por fabricar seus próprios meios de existência (mas sim que, na sociedade capitalista, o homem, ser pluridimensional, é reduzido a um mero animal laborans, a um simples apêndice das máquinas); não pensa ser a história feita central ou unicamente pela luta de classes (de tal maneira que o capitalismo não pode ser entendido unicamente em termos de exploração de uma classe pela outra), tampouco pensa a superação do capitalismo como unicamente a superação do "mercado", ou da classe dos capitalistas, com uma redivisão da riqueza que seguiria sendo produzida, grosso modo, da mesma maneira (mas sim como uma alteração radical do próprio modo de produzir as riquezas, e não unicamente no modo de distribuí-la). Por fim, não critica o capitalismo unicamente por este estar baseado em uma atividade exploratória (a usurpação da mais-valia), mas principalmente por esse sistema social ser, ao menos em grande medida, irracional e criar uma nova forma de dominação, não dos capitalistas sobre os trabalhadores, porém da própria lógica de valorização do capital sobre os indivíduos que servem a tal valorização, de sorte que estes não são autônomos em uma sociedade organizada de forma capitalista. Ao contrário, essa releitura foca explicitamente na intenção marxiana de fazer uma teoria crítica da sociedade contemporânea, da civilização capitalista, e, portanto, na tentativa marxiana de tornar inteligíveis as especificidades dessa forma sui generis de organizar o mundo social que se disseminou nos últimos quatro ou cinco séculos ${ }^{2}$.

\footnotetext{
${ }^{2}$ Cf. Postone, 1993; Jappe, 2006; Artous, 2006.
} 
Não é minha intenção demonstrar todas essas teses, as quais compartilho, aqui, mas sim articular, de modo breve, o sentido de emancipação na obra tardia marxiana. Para tanto, necessitarei delinear, mesmo que um pouco superficialmente, o diagnóstico de época do qual Marx parte e a crítica que esse autor dirige ao mundo que o circunda, ou, como este afirma, em O Capital, ao "mundo das mercadorias" (MARX, 2006, p. 199). Começarei, portanto, traçando o diagnóstico que Marx fez de sua época, mostrando as tensões e contradições da realidade social circundante, tensões e contradições estas que serviram como ponto de partida e perspectiva para a construção de sua crítica ao capitalismo. Em seguida, analisarei essa crítica, demonstrando tanto a forma pela qual Marx caracteriza o capitalismo quanto os motivos pelos quais ele o critica. Somente então tentarei discutir o significado da emancipação, defendendo que se trata, sobretudo, de uma emancipação do tipo de dominação característica da sociedade capitalista, a saber, uma dominação impessoal, abstrata, quase objetiva, das relações humanas reificadas sobre o conjunto da sociedade, e que essa emancipação acarretaria também uma emancipação do trabalho em prol da criação de cada vez mais tempo disponível. Tal tese, a meu ver, deve ainda ser o objetivo daqueles que propõem uma grande transformação político-social no mundo contemporâneo.

\section{UM MUNDO GRÁVIDO DE SEU CONTRÁRIO}

Antes de tudo, a teoria crítica da sociedade parte de um diagnóstico da época da qual ela mesma participa. E ela é, pode-se dizer assim, bastante audaciosa; não pretende apenas descrever a realidade social de modo mais acurado que as demais, mas também transformar essa realidade mesma ou, ao menos, oferecer à consciência de sua época uma crítica radical, que visa possibilitar a superação dos problemas que ela mesma aponta. Todavia, isso ainda não é tudo. A teoria crítica não parte, para realizar tal tarefa, de uma perspectiva exterior à sociedade, como um mais além, um ideal regulativo, uma utopia. Isto é, não estabelece um dever ser para julgar aquilo que é. Ao invés disso, busca, na própria realidade social, elementos emancipadores, cujo desenvolvimento traz racionalidade a um mundo ainda submetido, ao menos em grande parte, aos grilhões da ignorância e da superstição. Trata-se, portanto, de uma crítica imanente.

Marx pretende, em O Capital, esmiuçar o sistema capitalista, a fim de oferecer uma explicação do seu funcionamento interno, ou seja, almeja fazer um diagnóstico do sistema capitalista e, concomitantemente, criticá-lo de forma radical ${ }^{3}$.

\footnotetext{
${ }^{3}$ O próprio Marx define sua obra, então ainda inacabada, como sendo "[...] ao mesmo tempo uma descrição do sistema e, em virtude da descrição, uma crítica dele" (MARX, carta a Lassale, fevereiro de 1858, apud ROSDOLSKY, 2001, p. 479).
} 
Como teórico crítico, ele precisa, para cumprir seu projeto, encontrar na realidade capitalista elementos potenciais que podem, de algum modo, superar as críticas que ele mesmo levanta, transformando, por meio de seu próprio desenvolvimento, esse sistema social em uma nova forma de organização, mais racional do que a anterior.

Contudo, no mundo capitalista, o que pode permitir a nosso teórico oitocentista criticá-lo? Creio que aqui o melhor é dar a palavra a Marx, por meio da citação de parte de um texto no qual ele resume, de forma inusualmente breve e clara, o seu próprio diagnóstico:

Há um grande fato, característico deste nosso século XIX, que partido algum ousa negar. Por um lado, tem-se trazido à vida forças científicas e industriais das quais nenhuma época anterior na história humana teria suspeitado. Por outro, existem sintomas de decadência que ultrapassam os horrores registrados nos últimos tempos do Império Romano. Em nossos dias, tudo parece grávido de seu contrário: a maquinaria, dotada com o maravilhoso poder de encurtar e frutificar o trabalho bumano, leva-nos ao excesso de trabalbo e à inanição; as novas fontes de riqueza, por algum estranho e fatídico feitiço, tornam-se fontes de privação; as vitórias da arte parecem compradas com a perda do caráter. No mesmo ritmo em que a humanidade domina a natureza, o homem parece tornar-se escravo dos outros homens e de sua própria infâmia. Ainda a luz pura da ciência parece incapaz de brilhar senão contra o pano de fundo negro da ignorância. Todas as nossas invenções e progressos parecem resultar no endossar, com a vida intelectual, as forças materiais e no embrutecer a vida bumana, tornando-a uma força material. Este antagonismo entre a ciência e a indústria modernas, por um lado, e a dissolução e a miséria modernas, por outro; este antagonismo entre os poderes produtivos e as relações sociais de nossa época é um fato, palpável, avassalador e incontestável. (MARX, 1856, s.p., tradução e ênfase nossas).

Esse fragmento, um excerto do discurso de Marx na festa do quarto aniversário do jornal cartista People's Paper, aponta, claramente, para a tensão constitutiva da realidade capitalista. Essa tensão, "[...] que partido algum ousa negar", é aquela entre o que essa sociedade possui de mais avançado - as forças científicas e industriais, a maquinaria, que é "[...] dotada do poder de encurtar e frutificar o trabalho humano", as novas fontes de riqueza - e a forma pervertida por meio da qual isso tudo se realiza, que lembra e supera os horrores da decadência do império romano. $\mathrm{O}$ argumento central é que há, efetivamente, um grande progresso técnico no modo pelo qual os homens produzem as coisas que eles querem ou de que necessitam, e o termo "progresso" se refere ao fato de que, com menos esforço físico e um menor dispêndio de tempo, os homens são capazes de produzir mais e melhor do que antes, porém, "[...] por algum estranho e fatídico feitiço", a possibilidade que esse progresso técnico cria, a saber, trabalhar com menos esforço e durante menos tempo, não só não se efetiva como, através da aplicação da maquinaria que porta o progresso técnico, se realiza 
com o seguinte efeito perverso: ao invés de se trabalhar menos, se trabalha mais; ao invés de se reduzir o esforço, ele aumenta.

Mas como ocorre essa perversão? Ou, melhor ainda, por que ela ocorre? Para responder a essas duas novas questões, é útil dirigir-se a O Capital, precisamente àquela parte na qual Marx analisa a maquinaria e a grande indústria:

As contradições e os antagonismos inseparáveis da utilização capitalista da maquinaria não existem porque decorrem da própria maquinaria, mas de sua utilização capitalista! Já que, portanto, considerada em si, a maquinaria encurta o tempo de trabalho, enquanto utilizada como capital aumenta a jornada de trabalho; em si, facilita o trabalho, utilizada como capital aumenta sua intensidade; em si, é uma vitória do homem sobre a força da natureza, utilizada como capital submete o homem por meio da força da natureza; em si, aumenta a riqueza do produtor, utilizada como capital o pauperiza. (MARX, 1996, vol.2, p.73).

Nesse trecho, Marx diferencia a "maquinaria em si" da "maquinaria utilizada como capital", além de dizer que as contradições e antagonismos surgem unicamente da segunda e, precisamente, por causa da sua utilização capitalista. Eis então um elemento potencialmente emancipador (a maquinaria e o progresso técnico), na emaranhada realidade do mundo capitalista. E é a partir do potencial subjacente a esse elemento (a redução do tempo e do esforço do trabalho) que o mundo capitalista será criticado ${ }^{4}$. Uma possível crítica a tal argumento é a de que a técnica é neutra e que, portanto, não tem nada implícito nela mesma, isto é, que é arbitrário falar que a técnica, em si, serve para encurtar e frutificar o trabalho humano. Essa objeção é plenamente válida, uma vez que nada no martelo diz que ele serve para facilitar a entrada do prego na madeira e não para causar lesões no dedo, de maneira que apelar para a intenção original do fabricante pode, nesses casos, ser contraproducente, pois o que garante que o inventor da máquina a vapor a tenha inventado para poupar trabalho humano e não para, por exemplo, aumentar seus próprios ganhos? Ora, parece claro que a técnica pode ter, como de fato tem, mais de um uso possível e pode servir a diversas finalidades. O que Marx faz aqui é desnaturalizar o uso capitalista da maquinaria, mostrando uma alternativa possível, a saber, usá-la para reduzir (ou até mesmo abolir) o tempo de trabalho dos homens, ao invés de usá-la para aumentar o montante de valor criado, como se verá mais adiante. Limita-se, assim, a apontar outra opção de uso e, ao fazer isso, revela o núcleo irracional do uso capitalista da maquinaria ou, para manter a analogia, mostra que o martelo serve para mais coisas do que causar lesões no dedo.

\footnotetext{
4 "Esta crítica está enraizada não no que é, mas sim no que se tornou possível" (POSTONE, 1993, p. 360-1).
} 
É só com a análise da crítica que Marx faz ao capitalismo que poderemos responder à questão, até agora deixada em aberto, de como ocorrem, e por que ocorrem, os efeitos perversos acima constatados.

\section{A META Fetichista dA VALORIZAÇÃo CONTÍNUA}

Para responder ao questionamento proposto, é preciso, novamente, levantar algumas perguntas mais. São elas: no que consiste, para Marx, o capitalismo? E, afinal, por qual motivo ele é criticado? Estas não são questões simples, e não tentarei aqui senão oferecer uma resposta demasiado sucinta e, creio, um tanto superficial.

Segundo Marx, o capitalismo é um modo de produção que surgiu em princípios do século XVI, através de transformações nas corporações medievais, e que foi se generalizando ao longo dos séculos seguintes, de tal maneira que, com o tempo, passou a ser uma formação socioeconômica ${ }^{5}$, isto é, a forma pela qual a sociedade se organiza. Desse modo, pode-se dizer que o capitalismo hoje não apenas é o modo pelo qual produzimos aquilo de que necessitamos como também é o próprio mundo social no qual vivemos. Mas como Marx o define? Antes, porém, é preciso ver a própria definição de "capital". Contrariamente à economia política clássica, Marx não considera possível apreender o capital estaticamente, uma vez que o capital nada mais é do que um processo pelo qual o valor passa continuamente da forma mercadoria à forma dinheiro, transformando-se assim em um "sujeito automático":

Fixadas as formas particulares de aparição, que o valor que se valoriza assume alternativamente no ciclo de sua vida, então se obtêm as explicações: capital é dinheiro, capital é mercadoria. De fato, porém, o valor se torna aqui o sujeito de um processo em que ele, por meio de uma mudança constante das formas de dinheiro e mercadoria, modifica a sua própria grandeza, enquanto maisvalia se repele de si mesmo, enquanto valor original, se autovaloriza. Pois o movimento, pelo qual ele adiciona mais-valia, é seu próprio movimento, sua valorização, portanto autovalorização. (MARX, 1996, p. 273-4).

A definição de capital é, portanto, "valor que se autovaloriza". No primeiro capítulo de $O$ Capital, Marx define o valor como a forma pela qual algumas sociedades medem o trabalho despendido na produção de uma mercadoria para possibilitar o

\footnotetext{
5 “É o sociólogo polonês Julian Hochfeld que estabelece a distinção correta entre 'modo de produção', isto é, um modelo econômico 'puro', abstrato, e uma formação socioeconômica, isto é, um tipo concreto de sociedade no seio da qual um 'modo de produção' ocupa um lugar dominante. Assim, seria exato dizer que o modo de produção capitalista se desenvolveu na Grã-Bretanha a partir do século XVI; mas caracterizar a Grã-Bretanha como uma 'formação socioeconômica' capitalista, isso não seria exato senão a partir da segunda metade do século XVIII” (MANDEL, 1968, p. 135).
} 
intercâmbio com outra, de sorte que, nessa operação, tente se trocar montantes iguais de trabalho ${ }^{6}$. O capital surge somente quando as trocas mercantis já se disseminaram e o valor se encontra cristalizado na forma dinheiro, de tal maneira que o valor já possui uma existência própria, exterior às mercadorias. Em decorrência, o dinheiro poderá ser usado de tal forma que não apenas seja intercambiado infinitamente por mercadorias e novamente pela mesma quantia de dinheiro, mas sim em uma forma na qual aumente sua própria magnitude cada vez que passa de mercadoria novamente a dinheiro. Deve-se salientar, assim, que o capital possui uma existência autônoma frente aos indivíduos, mesmo àqueles que o possuem (os capitalistas), e que este tem como única finalidade o seu próprio crescimento.

Capitalismo, enquanto modo de produção, é o sistema no qual os meios de produção se tornam capital, ou seja, estes passam a ser propriedade de um indivíduo particular que os utiliza com o intuito de, por intermédio da produção de mercadorias, valorizar o dinheiro (nesse caso, um capital) que ele aí aplicou. Possui, assim, três características principais.

Em primeiro lugar, a separação do meio de produção do trabalhador e, por conseguinte, a transformação do trabalhador na mercadoria força de trabalho. Nos modos de produção que antecederam o capitalismo, o trabalhador vendia o seu trabalho já terminado (como grande parte dos artesãos até hoje o faz), ou era vendido ele próprio como escravo. Já no capitalismo, ele troca a si mesmo, ou melhor, a sua força de trabalho, em um determinado número de horas, para um capitalista que o usa para fabricar mercadorias e, em troca dela, lhe paga um salário. $\mathrm{O}$ meio de produção, a saber, o local e os instrumentos de trabalho, assim como a matéria-prima que será modificada e a força de trabalho contratada para modificála, pertencem ao capitalista, que os utilizará para produzir mercadorias e, nesse processo, obter mais-valia ${ }^{7}$ (o acréscimo de valor que se somará ao capital inicial).

A produção da mais-valia como meta da produção é a sua segunda característica. Grosso modo, os modos de produção anteriores tinham por meta a satisfação de necessidades, mesmo que estas fossem satisfeitas de forma indireta. Este é

${ }^{6}$ O que não significa, como muitos comentadores têm entendido (MANDEL, 1968, p. 51, GIANNOTTI, 2009, p. 82, ELSTER, 2005, p. 64), que Marx aceitou a teoria do valor-trabalho oriunda de Smith e Ricardo. Marx discorda desta por diversos motivos: o valor não é uma categoria trans-histórica, mas específica das sociedades mercantilistas; o trabalho não é a substância do valor, mas sim o trabalho abstrato socialmente necessário; e, principalmente, não há uma medição exata possível do dispêndio do tempo de trabalho, este repousa sobre bases fetichistas (salienta Rubin: "A teoria do fetichismo é, per se, a base de todo o sistema econômico de Marx, particularmente de sua teoria do valor" (RUBIN, 1987, p. 19). Cf. Rubin, 1987; Postone, 1993; Grespan, 2001.

${ }^{7}$ Para não me estender demais, não analisarei como o capital obtém mais-valia através da exploração da força de trabalho, única operação que permite a ele aumentar-se indefinidamente. A quem interessar possa, cf. Marx, 1872, cap. V. 
também o caso do capitalismo, mas não só. Se, por um lado, o trabalhador vende sua força de trabalho para obter um salário que lhe dê o que comer, continuando a ter como finalidade de sua ação laboriosa a satisfação de necessidades, por outro, o capitalista, ao aplicar seu capital na produção, não almeja senão a valorização do valor, o aumento incessante de seu capital. Há uma distinção que Marx faz, em O Capital, que exemplifica essa questão. Marx diferencia a riqueza material, a posse de objetos que permite a satisfação de necessidades (o fato de possuir um casaco que afugente o frio, por exemplo), da riqueza abstrata, a posse de uma quantia determinada de valor que pode tanto converter-se em uma riqueza material, quanto servir de capital para aumentar tal riqueza abstrata, quanto ainda ser simplesmente entesourada, guardada para um uso futuro. O capitalismo é essencialmente marcado pela intenção do detentor do capital de aumentar a sua riqueza abstrata, enquanto os modos anteriores de produção eram sempre caracterizados pela busca de uma maior riqueza material; isso não significa, contudo, que os problemas do capitalismo percebidos por Marx tenham origem em alguma disposição subjetiva do capitalista, como, por exemplo, a sua intenção particular. O papel do capitalista é apenas o de corporificar a própria categoria capital, representá-la. Por sinal, será o fato de possuir como finalidade a obtenção de mais valor que fará com que o capitalista aplique a maquinaria de tal maneira que aumente o tempo (e o esforço) de trabalho, ao invés de diminuí-lo, como adiante veremos. É ainda a busca incessante de mais valor que motivará o capitalista a aplicar o seu capital no desenvolvimento de novos mecanismos técnicos que possibilitem aumentar a quantidade de mercadorias produzidas e diminuir os seus custos individuais.

A terceira e última característica, porém não menos importante do que as anteriores, é a generalização da forma mercadoria ou, melhor dito, o fato da troca mercantil tornar-se a forma principal de inter-relação bumana. Nas formas sociais precedentes, a troca mercantil ocupava uma função muito menos importante do que na atual, ocorrendo, em grande parte, de forma acidental ou marginal. Somente com o advento do capitalismo e, em especial, quando este já é a formação socioeconômica e não mais apenas o modo de produção, que as pessoas passaram a se relacionar entre si principalmente através do intercâmbio de mercadorias. Segundo Marx, esse fato (de as pessoas se relacionarem por intermédio das mercadorias, e não diretamente) faz com que elas não sejam conscientes de seu modo de produção e, por um "estranho feitiço", sejam dominadas por este, ao invés de dominá-lo.

Como já explicitado antes, este é um processo que se desenvolve lentamente; surge por meio das corporações artesãs medievais e vai ganhando intensidade e se disseminando espacialmente, de modo que mal se podia dizer, na época em que Marx o diagnostica, que este se tornara um sistema global. Pelas suas próprias 
características principais, o capitalismo não se restringe ao "domínio" da economia, muito pelo contrário, uma de suas primeiras consequências práticas é a reificação das relações sociais, coisificadas pelo fato de os homens passarem a se relacionar entre si por intermédio das funções que ocupam no sistema produtivo, intercambiando seus ganhos (quase sempre salários) por mercadorias que "portam" trabalhos alheios. Assim, o capitalismo, enquanto formação socioeconômica, pode ser definido como a sociedade moldada, ao menos em grande parte, pelos desígnios desse "sujeito automático" que não quer, de jeito algum, parar de crescer.

Destarte, o que é característico do capitalismo é uma forma específica de dominação, a qual não pode ser reduzida, como quer o marxismo tradicional, a exploração de uma classe por outra. Sustentar que o capitalismo se baseia em uma operação exploratória, que nele o trabalho de uma classe de indivíduos é usurpado por outra, não possibilita diferenciá-lo das formas sociais anteriores, seja ela feudal, seja escravocrata, de castas etc. O que Marx percebe como específico do capitalismo é uma nova forma de dominação das categorias mesmas sobre o conjunto da sociedade humana; isto é, que uma determinada prática social - o intercâmbio de mercadorias - se reifica e se opõe à própria capacidade de agente dos indivíduos, passando a dominá-los. A esse processo Marx denomina "fetichismo". Quer capitalista, quer proletário, o indivíduo que participa de uma sociedade capitalista é, em grande parte, heterônomo, aceita as regras de funcionamento da sociedade ao invés de determiná-las juntamente com o conjunto de copartícipes. Quem dita as regras, grosso modo, é esse "sujeito automático", o capital, a reificação das relações sociais, visando um constante autocrescimento.

Não sem certa razão, o leitor objetará que, sendo o capital o sujeito (e também o objeto) do processo capitalista, a teoria marxiana assim apresentada torna-se "mecanicista"; objeção esta que, levada ao extremo, diria que não cabe aos homens a possibilidade de fazer algo, seja para abolir o capitalismo, seja para mudar seu curso. Lembrará ainda, quiçá, da tese de Vico, que é citada repetidas vezes e sempre afirmativamente por Marx, de que "[...] a história dos homens difere da história natural por termos feito uma e não a outra" (MARX, 1996, vol. 2, p. 8). Essa tese é, de fato, a formulação sucinta do materialismo que está sempre presente no pensamento desse autor. Mas dizer que os homens fazem a história humana não significa o mesmo de que eles são conscientes disto que produzem, ou, nas palavras de Marx: “[...] não o sabem, mas o fazem" (MARX, 1996, p. 200). O que há de específico no capitalismo, e é precisamente nisto que consiste, em grande parte, a crítica de Marx, é que este, na verdade, é um mecanismo no qual os homens estão engajados, mas do qual não possuem o controle. É o capitalismo, como forma de organização social, que é, portanto, "mecanicista", e não a teoria que o critica. É este que não dá espaço à subjetividade, enquanto conforma todas as relações sociais a meras coisas, toda 
a variedade das atividades humanas a uma mesma forma de dispêndio abstrato de tempo de trabalho. A história humana tem sido, assim, a história da heteronomia, a história da cegueira dos homens em construir conscientemente o seu mundo. Frente ao mecanicismo do capital, os homens podem (ou melhor, devem, ou ainda, em tempos de crise, precisam) se desengajar desse processo. A dominação específica do capitalismo, dominação desse mecanismo abstrato, quase objetivo, que é o capital, sobre os indivíduos só é possível porque os próprios indivíduos dela tomam parte, compartilham de seu fetichismo.

Esclarecido aquilo que caracteriza o capitalismo, a saber, a separação do trabalhador de seus meios de trabalho, a busca incessante de mais-valia como meta da produção e a reificação das relações sociais, culminando em um tipo de dominação abstrata específico dessa formação social, resta responder por qual motivo esse sistema social é criticado, motivo este que servirá igualmente de resposta à questão, ainda da primeira seção, de por que o potencial emancipador da maquinaria e do progresso técnico não só não se realiza como ainda se efetiva de modo perverso, isto é, com os efeitos contrários àqueles que poderiam ocorrer - lembrando, o progresso técnico poderia ter como efeito o aumento da produtividade do trabalho, de maneira a, com menos esforço e em menos tempo de trabalho, se produzir mais do que antes e se criar um excedente de tempo não mais ocupado por essa atividade.

A principal crítica de Marx ao sistema capitalista é a de que esse sistema social é regido pelo capital, e que este tem unicamente como meta a criação de mais valor. Para desnaturalizar esse determinado sistema e problematizá-lo, Marx mostra que também se poderia esperar (e, de certo modo, seria até mais razoável esperar) que o sistema social fosse regido pelos indivíduos que dele fazem parte e que estes se organizassem a fim de garantir uma melhoria da vida, a satisfação de necessidades ou mesmo simplesmente a realização de projetos conscientes ${ }^{8}$. Tendo unicamente a autovalorização como meta, o capital só vê a maquinaria como uma possibilidade de aumento de lucros o qual, para se efetivar, depende igualmente do aumento do tempo despendido no trabalho, fonte única do valor. Ao capital, verdadeiro sujeito desse processo, só importa a sua própria valorização. Resta a este um montante estratosférico de mercadorias para alocar em um mercado finito, tanto pela finitude das necessidades humanas - finitude esta que é bastante maleável, é verdade - quanto, principalmente, pela finitude do poder aquisitivo dos portadores

\footnotetext{
8 Trata-se da crítica principal, mas não da única. É certo que há inúmeras outras críticas, em especial a de que o capitalismo se baseia em uma operação exploratória e, portanto, injusta, a saber, a extração de mais-valia do trabalhador assalariado; assim como, por estar baseado em um antagonismo interno, entre a dimensão material do valor e da riqueza e sua dimensão abstrata, o capitalismo está sujeito a crises contínuas (sendo esta uma crítica funcional).
} 
dessas necessidades - cujo limite é bem mais palpável e sensível. Segundo a crítica marxiana, o mundo capitalista está de ponta-cabeça, com os homens servindo às coisas e não as coisas ao homem, e essa inversão é devida ao fetichismo da mercadoria, que faz com que os homens dotem as mercadorias de vida própria, tratando-as como se estas cristalizassem o tempo de trabalho deles mesmos. Em consequência, os homens submetem-se inconscientemente ao capital, passando a adorar o dinheiro tal como os "primitivos" adoravam os talismãs.

A superação do capitalismo é somente a mudança do agente social, do capital aos indivíduos, que implica a superação da meta do capital, ou melhor, o abandono dela. Para tanto, é preciso buscar algo que se ofereça como meta racional, capaz de reinverter a desordem mundana do capital. Que será isso? O elemento central, certamente, da emancipação...

\section{A emancipação ociosa}

Há um curioso panfleto anônimo, publicado em 1821 - cuja provável autoria é de Charles Wentworth Dilke, um owenita discípulo de William Godwin (cf. WALKER, s.d.) - que é citado repetidas vezes nos Grundrisse (cf. MARX, 2011, p. 321 e p. 589). Depois de criticar as abordagens mais comuns dos assuntos econômicos, Dilke afirma que os problemas da sociedade decorrem, em grande parte, do fato de os interesses (lucros, juros) do capital não diminuírem com o tempo, ou seja, a exploração do trabalho alheio continua acontecendo mesmo quando já se produziu aquilo que poderia ser consumido. Quando a sociedade consegue aumentar seu poder produtivo, destaca ele, a próxima consequência

[...] seria, por conseguinte, que onde os homens trabalharam até agora doze horas eles trabalhariam então seis, e isto é riqueza nacional, isto é prosperidade nacional. [...] Não há meio de se aumentar a riqueza de uma nação a não ser acrescentando facilidades para viver: assim esta riqueza é liberdade - liberdade para buscar recreação - liberdade para gozar a vida - liberdade para melhorar a mente: isto é tempo disponível, e nada mais. Quando a sociedade tiver chegado a este ponto, se os indivíduos que a compõe devem, nestas seis horas, lagartear no sol ou dormir na sombra, ou preguiçar, ou jogar [...], isto deve ser escolhido por cada homem individualmente. (DILKE, 1821, p. 5, tradução nossa).

Ora, essa consequência teria que ser o resultado da mecanização do trabalho se, e somente se, os homens tivessem por objetivo, na sua própria produção, a finalidade de poupar tempo de trabalho para despendê-lo em causas mais aprazíveis. Contudo, no sistema capitalista a produção tornou-se a sua própria finalidade, servindo meramente para valorizar o valor já existente. O que Dilke introduz com 
esse panfleto, e que Marx retomará explicitamente nos Grundrisse, mas também implicitamente em $O$ Capital, é que há algo de extremamente irracional no aumento indefinido da riqueza abstrata, e que seria muito mais lógico utilizar esse mecanismo (os meios de produção) não para produzir cada vez mais excedentes, mas sim para garantir a todos os indivíduos a maior parcela possível de tempo disponível (obviamente, garantindo ainda uma condição material confortável para todos, algo que não é difícil em se tratando de sociedades industriais altamente desenvolvidas caso hoje da maioria dos países, mesmo periféricos).

Entretanto, o que é tempo disponível? Adorno, em uma conferência radiofônica em 1969, aponta corretamente para o fato de o tempo livre, ao menos nas sociedades capitalistas tardias, ter como principal objetivo a reposição das energias para um novo dia de trabalho. Praticando hobbies ou contemplando celebridades da indústria cultural, os indivíduos não se distanciam de suas funções sociais, mesmo quando não estão ocupando os seus postos de trabalho, isto é, o trabalho se imiscui, a seu bel-prazer, também no tempo supostamente livre (cf. ADORNO, 1995). O século que separa O Capital dessa conferência de Adorno serve para abolir, certamente, a diferença rígida entre o tempo de trabalho e o tempo de lazer. O operário oitocentista deixava na porta da fábrica a sua função social, embora a fadiga de seu trabalho transformasse grande parte de seu tempo restante em descanso para um novo dia de labuta, assim como o embrutecimento ocasionado pela repetição incessante de movimentos quase mecânicos atrofiasse parte de sua capacidade criativa e intelectual. A linha que divide o tempo de trabalho do tempo supostamente livre é bem mais sutil para o prestador de serviços contemporâneo, seja porque, por intermédio de horas extras, cursos de capacitação ou aprimoramento etc., o tempo restante é diretamente colonizado pelo trabalho, seja porque, com o advento novecentista da indústria cultural (indústria da qual Adorno é, creio, o melhor teórico), esse tempo serve sobretudo para o consumo, que não deixa de ser uma forma de "servir" ao processo capitalista.

Dilke e Marx, contudo, não estão se referindo ao tempo supostamente livre da sociedade capitalista; aliás, o fato de este também servir como suporte ao processo capitalista só reforça a tese deles do irracionalismo desse sistema social. Com o conceito de tempo disponível, penso que eles aludem a um tempo que não é despendido com uma finalidade exterior à própria ação, isto é, se referem ao tempo gasto com ações que não visam a nada além, ações feitas, geralmente, pelo prazer decorrente delas. Um tipo de ação contraposta não só ao trabalho, ao menos como concebido nas sociedades capitalistas, como atividade penosa, labuta (não à toa, a palavra trabalho deriva, etimologicamente, de tripalium, um instrumento de tortura medieval), como também ao "tempo livre" da sociedade capitalista, da pausa do trabalho que deve ser preenchida, dotada de sentido, principalmente 
por atividades de consumo, servindo assim, quiçá sem que os indivíduos se deem conta disto, à valorização do valor. Tempo disponível é, por definição, um tempo não dominado, pressupondo, portanto, uma autonomia por parte daquele que o despende. É isso o que o capitalismo, como forma organizadora das relações sociais, nega ao indivíduo. Com o advento novecentista da indústria cultural, o capitalismo domina, por seus mecanismos abstratos, tanto o tempo de trabalho, que serve para a criação de valor, quanto o tempo pretensamente livre, tempo este ocupado com o consumo das mercadorias, algo igualmente necessário ao capital, pois este precisa de montantes maiores de consumo para poder oferecer igualmente montantes maiores de mercadorias, os quais possibilitam, novamente, a finalidade única do sujeito automático, a valorização do valor.

Há uma longa passagem no terceiro livro de $O$ Capital que merece ser citada na íntegra, uma vez que não apenas ilustra o argumento aqui exposto, mas mostra a centralidade do tema no pensamento marxiano, apesar dos poucos momentos em que aparece nas obras tardias. Ei-la:

A riqueza real da sociedade e a possibilidade de constante expansão de seu processo de produção não depende, portanto, da duração do mais-trabalho, mas de sua produtividade e das condições mais ou menos ricas de produção em que ela transcorre. O reino da liberdade só começa, de fato, onde cessa o trabalho determinado pela necessidade e pela adequação a finalidades externas; portanto, pela própria natureza da questão, isso transcende a esfera da produção material propriamente dita. Assim como o selvagem tem de lutar com a natureza para satisfazer suas necessidades, para manter e reproduzir sua vida, assim também o civilizado tem de fazê-lo, e tem de fazê-lo em todas as formas de sociedade e sob todos os modos de produção possíveis. Com seu desenvolvimento, ampliase esse reino da necessidade natural, pois se ampliam as necessidades; mas, ao mesmo tempo, ampliam-se as forças produtivas que as satisfazem. Nesse terreno, a liberdade só pode consistir em que o homem social, os produtores associados, regulem racionalmente esse seu metabolismo com a natureza, trazendo-o para seu controle comunitário, em vez de serem dominados por ele como se fora por uma força cega; que o façam com o minimo emprego de forças e sob as condições mais dignas e adequadas à sua natureza bumana. Mas este sempre continua a ser um reino da necessidade. Além dele é que começa o desenvolvimento das forças humanas, considerado como um fim em si mesmo, o verdadeiro reino da liberdade, mas que só pode florescer sobre aquele reino da necessidade como sua base. A redução da jornada de trabalho é a condição fundamental. (MARX, 1988, p. 255, itálico meu).

Essa passagem é crucial para meu argumento, pois ela tanto aponta para a crítica que Marx faz ao capitalismo, a saber, o fato de que as pessoas são dominadas por seu meio de produção - uma força que atua sobre elas cegamente, ao invés de elas o dominarem conscientemente - quanto indica no que consiste a superação desse problema, isto é, a sujeição do modo de produção para satisfazer 
os desejos do "homem social", que passa a se dedicar o mínimo possível para o "reino da necessidade". Aponta, aliás, até mesmo para o meio pelo qual é possível fazer a "revolução" - "a redução da jornada de trabalho" - tendo-se em vista, obviamente, que se trata não simplesmente de reduzi-la, mas, principalmente, de reinverter a finalidade da própria produção, quer dizer, não mais produção de riqueza abstrata, de mais valor, mas sim produção de riqueza real, de tempo disponível para todos.

Essa passagem também oferece um terceiro conceito de riqueza, que se contraporá à riqueza abstrata e à riqueza material, a saber, a riqueza real, o tempo que os homens têm no "reino da liberdade". Em tal raciocínio, a riqueza material é a base da riqueza real, já que esta segunda só pode se edificar quando o "reino da necessidade" é satisfeito e, de preferência, “[...] nas condições mais dignas e adequadas" possíveis.

\section{Conclusão}

Marx percebe, na possibilidade subjacente ao progresso tecnológico desenvolvido no modo capitalista de produção, algo que cria a oportunidade de tornar o mundo mais racional, algo, aliás, que permite criticar radicalmente a forma como o mundo social está organizado, tanto na sua como na nossa época. $\mathrm{Na}$ medida em que os homens conseguiram inventar máquinas e organizar o trabalho de tal maneira que este se tornou inúmeras vezes mais produtivo, eles poderiam também se ausentar cada vez mais do processo de produção, para se dedicar a atividades que lhes agradassem, fazendo-o com condições materiais bastante abundantes. Eis uma meta racional. Porém, ao invés de se servirem desses adventos para satisfazer seus desígnios, como que por um "estranho e fatídico feitiço", os homens continuaram trabalhando tanto ou mais, sem tornar esse trabalho mais agradável e sem conseguir que todos, ou ainda mesmo uma grande parte, fossem beneficiados com uma riqueza material suficiente para viver uma vida ao menos materialmente despreocupada. Para Marx, isso ocorreu (e ainda ocorre) porque os homens se submeteram cegamente a seu processo de produção, ao invés de dominá-lo, servindo assim como engrenagens em um mecanismo que visa somente à obtenção de cada vez mais valor, de modo que os homens seguem gastando a maior parte de suas existências na busca de algo que lhes possibilite satisfazer suas mais básicas necessidades, tal como antes do advento dessas maravilhosas engrenagens capazes de encurtar e frutificar a labuta.

Mesmo que Marx, aferrado ao lado negativo da dialética, nunca explicite positivamente no que consiste a sociedade comunista, ou no que consiste a superação do capitalismo, as suas negações vão aos poucos a determinando. Trata- 
se, podemos sabê-lo, de uma sociedade que deixa de ser mediada pelo valor, de maneira que os homens planificam, comunitariamente, a divisão dos produtos do trabalho; de uma sociedade na qual os trabalhadores associados tomam posse dos meios de produção, não trabalhando senão para si próprios; e, principalmente, de uma sociedade na qual a produção ocupa a mínima parcela possível de seus tempos, permitindo que as pessoas se dediquem, assim, a atividades mais condizentes com a sua natureza racional.

Que tal ideal de sociedade é totalmente oposto ao do socialismo realmente existente, socialismo este que erigiu o culto ao trabalho como religião oficial, é demasiado óbvio para se perder tempo com isso. Tão óbvio quanto o fato de que o "[...] antagonismo entre a ciência e indústria moderna, por um lado, e a dissolução e miséria moderna, por outro; este antagonismo entre os poderes produtivos e as relações sociais de nossa época", de que fala Marx no panfleto de 1856, anteriormente citado, continua sendo "[...] um fato, palpável, avassalador e incontestável".

FLECK, Amaro. Idle emancipation, or, what does Marx's critical theory propose? Trans/ Form/Ação, Marília, v. 35, n. 1, p. 73-88, 2012.

\begin{abstract}
In this paper I succinctly outline the standpoint from which Marx criticizes capitalism, namely, by pointing to the difference between the transforming potentiality of technology as developed under the capitalist mode of production, and its effective reality in this same system (part 1). On these grounds, I argue that Marx's critique of the capitalist system consists mainly in the fact that the permanent valorization of capital is the goal of production, and that this is an irrational aim which creates as a result an abstract form of domination over individuals (part 2). Finally, I reinterpret the meaning of emancipation in Marx's later thought, arguing that it refers to an emancipation from this abstract domination, culminating in an emancipation from work in favor of the creation of increased disposable time (part 3).
\end{abstract}

KEYWORDS: Karl Marx; critique of capitalism; critique of work; emancipation; disposable time. 


\section{REFERÊNCIAS}

ADORNO, Theodor. Tempo livre. Palavras e Sinais: modelos críticos 2. Tradução de Maria Helena Ruschel. Petrópolis: Vozes, 1995. p. 70-82.

ARTOUS, Antoine. Le fétichisme chez Marx. Paris: Syllepse, 2006.

[DILKE, Charles Wentworth]. The source and remedy of the national difficulties. Londres: Rowell and Martin, 1821.

ELSTER, Jon. An Introduction to Karl Marx. Cambridge: Cambridge University Press, 2005.

GIANNOTTI, José A. Marx: Além do marxismo. Porto Alegre: L\&PM, 2009.

GRESPAN, Jorge. Marx, crítico da teoria clássica do valor. Crítica Marxista, no ${ }^{\circ}$. São Paulo: Boitempo, 2001.

JAPPE, Anselm. As aventuras da mercadoria. Tradução de José Miranda Justo. Lisboa: Antígona, 2006.

MANDEL, Ernest. A formação do pensamento econômico de Karl Marx. Tradução de Carlos Henrique de Escobar. Rio de Janeiro: Jorge Zahar, 1968.

MARX, Karl. Speech at anniversary of the People's Paper. Disponivel em: < http://www. marxists.org/archive/marx/works/1856/04/14.htm>. Acesso em: jun. 2011. 1856.

. Grundrisse: Manuscritos econômicos de 1857 e 1858. Tradução de Mauro Duayer e Nélio Schneider. São Paulo: Boitempo; Rio de Janeiro: Ed. UFRJ, 2011.

. O Capital, livro I, 2 volumes. Tradução de Regis Barbosa e Flávio Kothe. São Paulo: Nova Cultural, 1996.

O Capital, Livro III, 2 volumes. Tradução de Regis Barbosa e Flávio Kothe. São Paulo: Nova Cultural, 1988.

POSTONE, Moishe. Time, labor and social domination. New York and Cambridge: Cambridge University Press, 1993.

ROSDOLSKY, Roman. Gênese e estrutura de O Capital. Tradução de César Benjamin. Rio de Janeiro: Contraponto, 2001.

RUBIN, Isaak Illich. A teoria marxista do valor. Tradução de José B. de S. Amaral Filho. São Paulo: Polis, 1987.

WALKER, Tom. Dilke's Source and Remedy: fictitious capital, unproductive labour, inconvertible paper money, superflous thing (preliminary draft). Disponível em: <http:// www.worklessparty.org/timework/srintro.pdf>. Acesso em: jun. 2011.

Recebido em: 25.10.2011

Aprovado em: 02.12.2011 